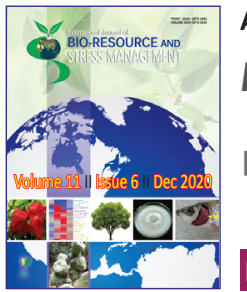

\title{
Effect of Plant Growth Regulator-Flora on the Growth and Yield of Transplanted Aman Rice
}

\author{
Nahid Hossain ${ }^{1}$, Alok Kumar Paul², Ishrat Alam²*, Md. Omar Ali Mollick ${ }^{2}$ and Shah Jalal Miajee ${ }^{2}$ \\ ${ }^{1}$ Dept. of Soil Science, Khulna Agricultural University, Khulna (9000), Bangladesh \\ ${ }^{2}$ Dept. of Soil Science, Sher-e-Bangla Agricultural University, Dhaka (1207), Bangladesh
}

\section{( \\ Open Access \\ Corresponding Author \\ Ishrat Alam \\ e-mail: ishratshanta@sau.edu.bd}

Citation: Hossain et al., 2020. Effect of Plant Growth Regulator-Flora on the Growth and Yield of Transplanted Aman Rice. International Journal of Bio-resource and Stress Management 2020, 11(6), 542-547. HTTPS://DOI.ORG/10.23910/1.2020.2155.

Copyright: (c) 2020 Hossain et al. This is an open access article that permits unrestricted use, distribution and reproduction in any medium after the author(s) and source are credited.

Data Availability Statement: Legal restrictions are imposed on the public sharing of raw data. However, authors have full right to transfer or share the data in raw form upon request subject to either meeting the conditions of the original consents and the original research study. Further, access of data needs to meet whether the user complies with the ethical and legal obligations as data controllers to allow for secondary use of the data outside of the original study.

Conflict of interests: The authors have declared that no conflict of interest exists.

\begin{abstract}
The experiment was conducted in the farm area of Sher-e-Bangla Agricultural University, Sher-e-Bangla Nagar, Dhaka during the period of July to November, 2015 to find out the effect of plant growth regulator-flora on the growth and yield of transplanted aman rice (BR 11-Mukta). The experiment comprised of 8 treatments as- $T_{0}$ : Control condition (No chemical fertilizer, no Flora), $T_{1}$ : Recommended Fertilizer Doses-RFD $\left(120,20,80,16\right.$ and $2 \mathrm{~kg} \mathrm{ha}^{-1}$ of N, P, K, S and $Z n$, respectively), $T_{2}: R F D+1$ time spray of Flora, $T_{3}: R F D+2$ times spray of Flora, $\mathrm{T}_{4}: 1 / 2 \mathrm{RFD}+1$ time spray of Flora, $\mathrm{T}_{5}: 1 / 2 \mathrm{RFD}+2$ times spray of Flora, $\mathrm{T}_{6}$ : No chemical fertilizer+1 time spray of Flora and $T_{7}$ : No chemical fertilizer+2 times spray of Flora. Data on different yield contributing characters, yield, and characteristics of post-harvest soil was recorded and significant variation was observed for different treatments. At harvest, the tallest plant $(117.60 \mathrm{~cm})$ was recorded from $\mathrm{T}_{3}$, while the shortest plant $(88.85 \mathrm{~cm})$ in $\mathrm{T}_{0}$ treatment. The highest number of filled grains panicle ${ }^{-1}$ (86.27) was recorded in $T_{3}$, whereas the lowest number (68.53) in $\mathrm{T}_{0}$ treatment. The highest grain yield $\left(5.13 \mathrm{t} \mathrm{ha}^{-1}\right)$ was recorded in $\mathrm{T}_{3^{\prime}}$ while the lowest $\left(2.78 \mathrm{t} \mathrm{ha}^{-1}\right)$ in $\mathrm{T}_{0}$ treatment. The highest total nitrogen $(0.632 \%)$ was recorded from $\mathrm{T}_{3}$, while the lowest $(0.369 \%)$ in $\mathrm{T}_{0}$ treatment.
\end{abstract}

Keywords: Plant growth regulator, flora, yield, growth, transplanted aman

\section{Introduction}

Rice (Oryza sativa L.) is the world's most important staple food; it can support more than half of the world's population (Davidson et al., 2014). In worldwide, 474.86 million metric tons of rice was produced from 159.64 million hectares of land during the year of 2014-15 (Anonymous, 2015). Global rice production in 2016 was up to about 749 million t, superseded by maize with a yield of 959 million $t$ (Wang et al., 2017). About $84.67 \%$ of cropped area of Bangladesh is used for rice production, with annual production of 30.42 million tons from 10.4 million hectare of land (Anonymous, 2014). Among different rice growing seasons, transplant aman cover about $49.11 \%$ and it contributes to $38.11 \%$ of the total rice production in the country (Anonymous, 2014). Rice yields are either decelerating/stagnating/declining in post green revolution era mainly due to imbalance in fertilizer use, soil degradation, irrigation and weeding schedule, type of cropping system practiced, lack of suitable rice

\section{Article History}

RECEIVED in $02^{\text {nd }} 0$ ctober 2020 RECEIVED in revised form $18^{\text {th }}$ November 2020 ACCEPTED in final form $07^{\text {th }}$ December 2020 
variety for low moisture adaptability and disease resistance (Prakash, 2010).

Now day's different high yielding and hybrid rice varieties are available in Bangladesh which has more yield potentiality (Bhuiyan et al., 2014). At present there is a very little scope for horizontal expansion of rice production in Bangladesh. So the farmers and agricultural scientists are diverting their attention towards vertical expansion for increased crop production. Nowadays, it is therefore crucial to boost rice yield in limited cultivated land area per capita to meet the food demands of the increasing worldwide population. Several alternative counter-measures, including developing water conservancy projects, ameliorating soil qualities, popularizing techniques of plant protection and cultivation as well as the application of fertilizers have been implemented (Yuan, 2014). Therefore, attempts should be taken to increase the yield per unit area through the use of modern production technologies that included, use of quality seeds, high yielding and hybrid varieties, optimum age of seedling, optimum number of seedling hill-1, adopting proper plant protection measures, seedling raising techniques and fertilizer management. In Bangladesh, on an average to produce one ton of rice grain of high-yielding varieties is removed about $22 \mathrm{~kg} \mathrm{~N}, 7 \mathrm{~kg} \mathrm{P}_{2} \mathrm{O}_{5}$, $32 \mathrm{~kg} \mathrm{~K} \mathrm{O}_{2}, 5 \mathrm{~kg} \mathrm{MgO}, 4 \mathrm{~kg} \mathrm{CaO}, 1 \mathrm{~kg} \mathrm{~S}$ and $40 \mathrm{~g} \mathrm{Zn}$ from the soil (Chaudhary et al., 2007). Emergence of widespread multinutrient deficiencies, depletion of native nutrient reserves, imbalanced fertilization are of utmost concern, causing serious stagnation in yields and declining productivity of various rice ecosystems (Rai, 2006). Excess use of fertilizer nutrients implies increase of cost and decreases of returns and risk of environmental and soil pollution (Sharma et al., 2003). The combination of inefficiency and excess fertilizer use has adverse impacts on water, soil, climate and biodiversity (Ma et al., 2014). On the other hand, under use of nutrients depress the scope for increasing the present level of nutrients to the economically optimum level to exploit production potential to a larger extent (Singh et al., 2001). So, application of inadequate and unbalanced fertilization to crops is the results of low crop yields.

Plant growth regulators (PGRs) are organic compounds, other than nutrients that modify plant physiological processes and also called biostimulants or bioinhibitors that act inside plant cells to stimulate or inhibit specific enzymes or enzyme systems and thus regulate plant metabolism (Rahman et al., 2017). Flora is a plant growth regulator containing $20 \%$ Nitro Benzene and acts as a plant energizer, flowering stimulant and yield booster. The use of plant growth regulator (PGR) in rice in Bangladesh is very little so the requirement is to properly understand the PGR to enhance high yield and quality. Suitable PGR are necessary for sustainable agriculture that will provide maximum rice production with good quality (Aziz and Miah, 2009). The PGRs regulated $\mathrm{N}_{2} \mathrm{O}$ transport by manipulating anatomical and physiological processes and its application can be suitable for $\mathrm{N}_{2} \mathrm{O}$ emission reduction coupled with an increase in economic productivity (Mohapatra et al., 2018). PGR have now been applied to a large variety of plant organs in several ways and it has been found to greatly enhance stem elongation as its most striking effect. They act inside plant cells and play important roles in plant growth, yield and quality formation of crops (Ekamber and Kumar, 2007). PGR increase the active Fe content in leaves and alleviate rice chlorosis in practical use (Zhang et al., 2017). Furthermore, PGRs regulate the amount, type and direction of plant growth with remarkable accomplishments of improved plant development and enhanced yield in several crops been documented (Shah et al., 2006; Emongor, 2007). It regulates cell elongation, tissue swelling, cell division and formation of adventitious roots, among others (Woodward and Bartel, 2005; Abel and Theologis, 2010) and also participates in the regulation of growth and development processes (Sakamoto et al., 2004; Mohammed and Tarpley, 2011; Fahad et al., 2015). PGR increases $14.3 \%$ increase in the number of rice panicles (Banful and Attivor, 2017). Application of PGR Partially alleviated the detrimental effects of rice senescence by modulating the activity of enzymatic antioxidants, and improving antioxidant system, which helped in sustaining plant growth (Pan et al., 2013). Based on above discussion the research work was designed with the objective to evaluate the growth and yield of transplanted aman rice due plant growth regulators-flora.

\section{Materials and Methods}

\subsection{Experimental period and location}

The experiment was conducted during the period of July to November, 2015 in the farm area of Sher-e-Bangla Agricultural University, Sher-e-Bangla Nagar, Dhaka. The location of the site is $23^{\circ} 74^{\prime} \mathrm{N}$ latitude and $90^{\circ} 35^{\prime} \mathrm{E}$ longitude with an elevation of 8.4 meter above from sea level.

\subsection{Soil characteristics}

The land type of the experimental soil were high land with general soil type is Shallow Red Brown Terrace soil and the soil belongs to the Tejgaon series under the Agro-ecological Zone of Madhupur Tract (AEZ-28). A composite sample of the experimental field was made by collecting soil from several spots of the field at a depth of $0-15 \mathrm{~cm}$ before initiation of the experiment. The collected soil was air-dried, grind and passed through $2 \mathrm{~mm}$ sieve and analyzed at Soil Resources Development Institute (SRDI), Farmgate, Dhaka for some important physical and chemical properties. The soil was having a texture of silty clay with $\mathrm{pH}$ and organic matter 6.31 and $1.31 \%$, respectively. The results showed that the soil composed of $27 \%$ sand, $43 \%$ silt and $30 \%$ clay. In the soil, the total $\mathrm{N}(\%)$, available $\mathrm{P}$ (ppm), exchangeable $\mathrm{K}$ (me/100 g soil) and available S (ppm) were 0.06\%, 19.85 ppm, 0.12 me/100 g soil and $14.40 \mathrm{ppm}$ respectively.

\subsection{Planting material and treatment of the experiment}

In this experiment BR 11 (Mukta) was used as the test crop which was developed at the Bangladesh Rice Research 
Institute from the cross between BR 52-87-1-HR88 and IR20/ IR5-47-2 in 1980.

The experiment comprised of the following 8 treatment:

$\mathrm{T}_{0}$ : Control condition (No chemical fertilizer, no Flora), $\mathrm{T}_{1}$ : Recommended Fertilizer Doses-RFD (120, 20, 80, 16 and $2 \mathrm{~kg}$ ha $^{-1}$ of $N, P, K, S$ and $Z n$, respectively), $T_{2}: R F D+1$ time spray of Flora, $T_{3}: R F D+2$ times spray of Flora, $T_{4}: 1 / 2 R F D+1$ time spray of Flora, $T_{5}: 1 / 2$ RFD +2 times spray of Flora, $T_{6}:$ No chemical fertilizer +1 time spray of Flora, $\mathrm{T}_{7}$ : No chemical fertilizer +2 times spray of Flora

\subsection{Experimental design}

The experiment was laid out in Randomized Complete Block Design (RCBD) with three replications. An area of $29.5 \times 14.5$ $\mathrm{m}^{2}$ was divided into 3 blocks. The size of the each unit plot was $3.5 \times 2.5 \mathrm{~m}^{2}$. The space between two blocks and two plots were $0.75 \mathrm{~m}$ and $0.5 \mathrm{~m}$, respectively.

\subsection{Fertilizers and manure application}

The fertilizers $N, P, K, S$ and $Z n$ in the form of urea, TSP, MoP, Gypsum and zinc sulphate, respectively were applied @ 120 $\mathrm{kg}, 20 \mathrm{~kg}, 80 \mathrm{~kg}, 16 \mathrm{~kg}$ and $2.0 \mathrm{~kg} \mathrm{ha}^{-1}$. The entire amounts of TSP, MoP, gypsum and zinc sulphate were applied during the final preparation of experimental plot. Urea was applied in two equal installments as top dressing at tillering and panicle initiation stages.

\subsection{Application of PGR-Flora}

PGR-Flora was collected from Siddique Bazaar, Dhaka and applied as per treatment with mixing $2.0 \mathrm{ml}$ Flora with 500 $\mathrm{ml}$ water for per plot. $1^{\text {st }}$ spray was done at 5 September and $2^{\text {nd }}$ spray at 20 September, 2015 in the specific plot as per treatment.

\subsection{Sampling and data collection}

Data on different parameters were counted from 10 selected hills and average value was recorded. After harvest of crop soil samples were collected from each plot at a depth of 0 to $15 \mathrm{~cm}$. Soil samples of each plot was air-dried, crushed and passed through a two $\mathrm{mm}$ ( 10 meshes) sieve. Data on different yield contributing characters, yield and nutrient status of post-harvest soil were statistically analyzed.

\section{Results and Discussion}

\subsection{Yield attributes and yield of rice}

Statistically significant variation was recorded in terms of different yield attributes and yield of rice due to the effect of different treatments (Table 1). At 40 DAT, the longest plant $\left(25.76 \mathrm{~cm}\right.$ ) was observed in $\mathrm{T}_{3}$ (RFD+2 times spray of Flora) which was statistically similar $(25.33 \mathrm{~cm}, 24.32 \mathrm{~cm}, 23.29 \mathrm{~cm}$, $22.27 \mathrm{~cm}, 22.00 \mathrm{~cm}$ and $21.44 \mathrm{~cm}$, respectively) to $\mathrm{T}_{2}$ (RFD+1 time spray of Flora), $T_{1}$ (Recommended Fertilizer Doses-RFD: $120,20,80,16$ and $2 \mathrm{~kg} \mathrm{ha}^{-1}$ of N, P, K, S and Zn, respectively), $T_{5}\left(1 / 2 R F D+2\right.$ times spray of Flora), $T_{4}(1 / 2 R F D+1$ time spray of Flora), $T_{7}$ (No chemical fertilizer+2 times spray of Flora) and
Table 1: Effect of plant growth regulator-flora on plant height at different days after transplanting (dat) and harvest of transplanted aman rice

\begin{tabular}{lccccc}
\hline Treatments & \multicolumn{5}{c}{ Plant height $(\mathrm{cm})$ at } \\
\cline { 2 - 6 } & 40 DAT & 50 DAT & 60 DAT & 70 DAT & Harvest \\
\hline $\mathrm{T}_{0}$ & $18.60^{\mathrm{b}}$ & $41.90^{\mathrm{d}}$ & $62.96^{\mathrm{c}}$ & $73.27^{\mathrm{d}}$ & $88.85^{\mathrm{b}}$ \\
$\mathrm{T}_{1}$ & $24.32^{\mathrm{a}}$ & $51.76^{\mathrm{ac}}$ & $79.97^{\mathrm{ab}}$ & $91.96^{\mathrm{a}-\mathrm{c}}$ & $112.80^{\mathrm{a}}$ \\
$\mathrm{T}_{2}$ & $25.33^{\mathrm{a}}$ & $52.73^{\mathrm{ab}}$ & $81.61^{\mathrm{ab}}$ & $93.51^{\mathrm{ab}}$ & $115.00^{\mathrm{a}}$ \\
$\mathrm{T}_{3}$ & $25.76^{\mathrm{a}}$ & $54.24^{\mathrm{a}}$ & $83.42^{\mathrm{a}}$ & $97.81^{\mathrm{a}}$ & $117.60^{\mathrm{a}}$ \\
$\mathrm{T}_{4}$ & $22.27^{\mathrm{ab}}$ & $48.24^{\mathrm{bc}}$ & $74.37^{\mathrm{a}-\mathrm{c}}$ & $85.59^{\mathrm{bc}}$ & $108.56^{\mathrm{a}}$ \\
$\mathrm{T}_{5}$ & $23.29^{\mathrm{a}}$ & $49.33^{\mathrm{ac}}$ & $76.55^{\mathrm{ab}}$ & $88.91^{\mathrm{a}-\mathrm{c}}$ & $110.56^{\mathrm{a}}$ \\
$\mathrm{T}_{6}$ & $21.44^{\mathrm{a}}$ & $46.73^{\mathrm{cd}}$ & $70.51^{\mathrm{bc}}$ & $82.03^{\mathrm{cd}}$ & $107.19^{\mathrm{a}}$ \\
$\mathrm{T}_{7}$ & $22.00^{\mathrm{ab}}$ & $47.62^{\mathrm{bc}}$ & $73.83^{\mathrm{a}-\mathrm{c}}$ & $83.70^{\mathrm{bc}}$ & $109.25^{\mathrm{a}}$ \\
LSD & 3.906 & 5.047 & 10.66 & 9.435 & 10.07 \\
$(p=0.05)$ & & & & & \\
Significance & 0.05 & 0.01 & 0.05 & 0.01 & 0.01 \\
level & & & & & \\
\hline
\end{tabular}

In a column means having similar letter(s) are statistically identical and those having dissimilar letter(s) differ significantly as per 0.05 level of probability

$\mathrm{T}_{6}$ (No chemical fertilizer+1 time spray of Flora), whereas the shortest plant $\left(18.60 \mathrm{~cm}\right.$ ) was observed in $\mathrm{T}_{0}$ (Control condition i.e. no chemical fertilizer, no flora) treatment. Similar tends of results also recorded at 50, 60 and 70 DAT. At harvest, the tallest plant $(117.60 \mathrm{~cm})$ was recorded from $T_{3}$ treatment, which was statistically similar with other treatment except $T_{0}$, while the shortest plant $(88.85 \mathrm{~cm})$ was found in $\mathrm{T}_{0}$ treatment. Generally plant height is a genetical character and it is controlled by the genetic make-up of the varieties and different varieties produced different size of plant but management practices also influenced it. Ndaeyo et al. (2008) reported that NPK $(15: 15: 15)$ fertilizer rate significantly increased plant height.

The highest number of effective tillers hill ${ }^{-1}$ (16.13) was found in $T_{3}$ which was statistically similar $(15.80,15.33$, 14.73, 14.60 and 14.20, respectively) to $T_{2}, T_{1}, T_{5}, T_{7}$ and $T_{4^{\prime}}$ and closely followed (13.87) by $T_{6^{\prime}}$, while the lowest number of effective tillers hill ${ }^{-1}$ (10.27) was recorded in $\mathrm{T}_{0}$ treatment (Table 2). The lowest number of ineffective tillers hill ${ }^{-1}(2.27)$ was observed in $\mathrm{T}_{3}$ which was statistically similar (2.40) to $T_{2}$ and closely followed (2.67) by $T_{1}$. On the other hand, the highest number (4.33) was found in $T_{0}$ treatment. The highest number of total tillers hill ${ }^{-1}(18.40)$ was found in $T_{3}$ which was statistically similar with other treatment except $\mathrm{T}_{0}$, while the lowest number of total tillers hill-1 (14.60) was observed in $\mathrm{T}_{0}$ treatment. Ndaeyo et al. (2008) reported that NPK (15:15:15) fertilizer rate significantly increased tillers per plant. The highest number of filled grains panicle ${ }^{-1}(86.27)$ was recorded in $\mathrm{T}_{3}$ which was statistically similar $(84.27,81.73$, 


\begin{tabular}{|c|c|c|c|c|c|c|}
\hline Treatments & $\begin{array}{l}\text { No. of effective } \\
\text { tillers hill }{ }^{-1}\end{array}$ & $\begin{array}{l}\text { No. of in-effective } \\
\text { tillers hill }\end{array}$ & $\begin{array}{l}\text { No. of total } \\
\text { tillers hill }{ }^{-1}\end{array}$ & $\begin{array}{l}\text { No. of filled } \\
\text { grains panicle-1 }\end{array}$ & $\begin{array}{l}\text { No. of unfilled } \\
\text { grains panicle }^{-1}\end{array}$ & $\begin{array}{l}\text { No. of total } \\
\text { grains panicle }\end{array}$ \\
\hline $\mathrm{T}_{0}$ & $10.27^{c}$ & $4.33^{\mathrm{a}}$ & $14.60^{b}$ & $68.53^{c}$ & $9.67^{a}$ & $78.20 \mathrm{~b}$ \\
\hline $\mathrm{T}_{1}$ & $15.33^{\mathrm{ab}}$ & $2.67^{d}$ & $18.00^{\mathrm{a}}$ & $81.67^{\mathrm{ab}}$ & $7.13^{b-d}$ & $88.80^{a}$ \\
\hline$T_{2}$ & $15.80^{\mathrm{ab}}$ & $2.40^{\mathrm{de}}$ & $18.20^{\mathrm{a}}$ & $84.27^{\mathrm{ab}}$ & $6.60^{\text {cd }}$ & $90.87^{a}$ \\
\hline $\mathrm{T}_{3}$ & $16.13^{\mathrm{a}}$ & $2.27^{e}$ & $18.40^{\mathrm{a}}$ & $86.27^{a}$ & $6.13^{d}$ & $92.40^{\mathrm{a}}$ \\
\hline $\mathrm{T}_{4}$ & $14.20^{\mathrm{ab}}$ & $3.20^{c}$ & $17.40^{\mathrm{a}}$ & $80.20^{\mathrm{ab}}$ & $7.27^{b-d}$ & $87.47^{a}$ \\
\hline $\mathrm{T}_{5}$ & $14.73^{\mathrm{ab}}$ & $3.07^{c}$ & $17.80^{\mathrm{a}}$ & $81.73^{\mathrm{ab}}$ & $7.00^{b-d}$ & $88.73^{a}$ \\
\hline $\mathrm{T}_{6}$ & $13.87^{b}$ & $3.67^{b}$ & $17.53^{\mathrm{a}}$ & $77.60^{b}$ & $8.20^{b}$ & $85.80^{\mathrm{ab}}$ \\
\hline $\mathrm{T}_{7}$ & $14.60^{\mathrm{ab}}$ & $3.33^{c}$ & $17.93^{\mathrm{a}}$ & $79.40^{\mathrm{ab}}$ & $7.60^{\mathrm{bc}}$ & $87.00^{\mathrm{a}}$ \\
\hline $\operatorname{LSD}(p=0.05)$ & 1.963 & 0.271 & 2.130 & 7.367 & 1.150 & 7.799 \\
\hline $\begin{array}{l}\text { Significance } \\
\text { level }\end{array}$ & 0.01 & 0.01 & 0.05 & 0.01 & 0.01 & 0.05 \\
\hline
\end{tabular}

In a column means having similar letter(s) are statistically identical and those having dissimilar letter(s) differ significantly as per 0.05 level of probability

$81.67,80.20$ and 79.40, respectively) to $T_{2}, T_{5}, T_{1}, T_{4}$ and $T_{7}$, and closely followed (77.60) by $T_{6}$, whereas the lowest number of filled grains panicle ${ }^{-1}(68.53)$ was found in $T_{0}$ treatment. The lowest number of unfilled grains panicle ${ }^{-1}(6.13)$ was observed in $T_{3}$ which was statistically similar $(6.60,7.13$ and 7.27 , respectively) to $T_{2}, T_{1}$ and $T_{4}$, whereas the highest number of unfilled grains panicle ${ }^{-1}$ (9.67) was found in $T_{0}$ treatment. The highest number of total grains panicle $e^{-1}$ (92.40) was found in $\mathrm{T}_{3}$ which was statistically similar with other treatments except $\mathrm{T}_{0}$, while the lowest number of total grains panicle ${ }^{-1}$ (78.20) was recorded in $T_{0}$ treatment. Vetayasuporn (2012) reported that chemical fertilizer) which gave the highest total number panicle per hill (14.82).

The longest panicle $(25.78 \mathrm{~cm})$ was observed in $T_{3}$ which was statistically similar $(25.05 \mathrm{~cm}, 24.37 \mathrm{~cm}$ and 23.95, respectively) to $T_{2}, T_{1}$ and $T_{5}$, and closely followed (22.61) by $\mathrm{T}_{4}$, whereas the shortest panicle $(18.79 \mathrm{~cm})$ was observed in $\mathrm{T}_{0}$ treatment which was statistically similar $(20.16 \mathrm{~cm}$ and 21.16 $\mathrm{cm}$ ) to $\mathrm{T}_{6}$ and $\mathrm{T}_{7}$ and they were statistically similar (Table 3 ). The highest weight of 1000 grains (20.92 g) was recorded in $\mathrm{T}_{3}$ which was statistically similar with other treatment except $\mathrm{T}_{0}$, while the lowest weight of 1000 grains (18.03 g) was observed in $\mathrm{T}_{0}$ treatment. The highest grain yield $\left(5.13 \mathrm{t} \mathrm{ha}^{-1}\right)$ was recorded in $\mathrm{T}_{3}$ which was followed $(4.41,4.24$ and $4.05 \mathrm{t}$ $\mathrm{ha}^{-1}$ ) by $\mathrm{T}_{2}, \mathrm{~T}_{1}$ and $\mathrm{T}_{5}$, respectively, while the lowest grain yield (2.78 $\left.\mathrm{t} \mathrm{ha}^{-1}\right)$ was observed in $\mathrm{T}_{0}$ treatment. Haq et al. (2002) reported that $90 \mathrm{~kg} \mathrm{~N}+50 \mathrm{~kg} \mathrm{P}_{2} \mathrm{O}_{5}+40 \mathrm{~kg} \mathrm{~K}_{2} \mathrm{O}+10 \mathrm{~kg} \mathrm{~S}+4 \mathrm{~kg}$ $\mathrm{Zn} \mathrm{ha-1}+$ diazinon gave the highest grain yields. Rahman (2017) reported that in rice-rice cropping pattern, the highest grain yield of Boro rice was recorded in the soil test basis (STB) N P $\mathrm{K}$ S Zn fertilizers treatment while in T. Aman rice the $75 \%$ or $100 \%$ of N P K S Zn (STB) fertilizers plus green manure (GM) with or without cowdung gave the highest or a comparable yield. The highest straw yield $\left(5.31 \mathrm{t} \mathrm{ha}^{-1}\right)$ was found in $T_{3}$ which was statistically similar $\left(5.15,5.06\right.$ and $\left.4.82 \mathrm{t} \mathrm{ha}^{-1}\right)$ to
$\mathrm{T}_{2}, \mathrm{~T}_{1}$ and $\mathrm{T}_{5}$, respectively, where the lowest straw yield (4.32 $\mathrm{t} \mathrm{ha}^{-1}$ ) was recorded in $\mathrm{T}_{0}$ treatment which was statistically similar (4.39 $\mathrm{t} \mathrm{ha}^{-1}$ and $\left.4.53 \mathrm{t} \mathrm{ha}^{-1}\right)$ to $\mathrm{T}_{6}$ and $\mathrm{T}_{4}$ treatment. Haq et al. (2002) reported that $90 \mathrm{~kg} \mathrm{~N}+50 \mathrm{~kg} \mathrm{P}_{2} \mathrm{O}_{5}+40 \mathrm{~kg} \mathrm{~K}_{2} \mathrm{O}+10$ $\mathrm{kg} \mathrm{S}+4 \mathrm{~kg} \mathrm{Zn} \mathrm{ha-1+diazinon} \mathrm{gave} \mathrm{the} \mathrm{highest} \mathrm{straw} \mathrm{yields.} \mathrm{The}$ highest biological yield (10.44 $\left.\mathrm{t} \mathrm{ha}^{-1}\right)$ was recorded in $\mathrm{T}_{3}$ which was statistically similar $\left(9.56,9.30\right.$ and $\left.8.88 \mathrm{t} \mathrm{ha}^{-1}\right)$ to $\mathrm{T}_{2}, \mathrm{~T}_{1}$ and $T_{5}$, respectively and closely followed $\left(8.29 \mathrm{t} \mathrm{ha}^{-1}\right)$ by $T_{4}$, while the lowest biological yield $\left(7.10 \mathrm{t} \mathrm{ha}^{-1}\right)$ was observed in $T_{0}$ treatment which was statistically similar (7.71 t ha-1 and 7.97 t ha ${ }^{-1}$ ) to $T_{6}$ and $T_{7}$ treatment (Table 3). The highest harvest index (46.31\%) was found in $\mathrm{T}_{3}$ which was statistically similar with other treatment except $\mathrm{T}_{1}$ and $\mathrm{T}_{7}$ and closely followed $(42.78 \%)$ by $T_{7}$ and the lowest harvest index (39.18\%) was obtained in $\mathrm{T}_{0}$ treatment.

3.2. Soil $p H$, organic matter total $N$, available $P$ and exchangeable $K$ in post-harvest soil

Different post-harvest soil characteristics showed statistically differences due to the effect of different treatments (Table 4). The highest soil $\mathrm{pH}$ (6.15) was found from $\mathrm{T}_{3}$ treatment, whereas the lowest soil $\mathrm{pH}$ (5.73) was observed from $\mathrm{T}_{0}$ treatment. The highest organic matter (1.46\%) was recorded from $\mathrm{T}_{3}$ treatment and the lowest organic matter (1.33\%) was found from $\mathrm{T}_{0}$ treatment. The highest total nitrogen $(0.632 \%)$ was recorded from $\mathrm{T}_{3}$ treatment which was statistically similar with other treatmnet except $\mathrm{T}_{0}$ and $\mathrm{T}_{6}$, while the lowest total nitrogen $(0.369 \%)$ was observed from $T_{0}$ treatment. The highest available phosphorus (32.59\%) was recorded from $\mathrm{T}_{3}$ treatment which was statistically similar (31.92\%, 30.11\% and $29.19 \%$, respectively) to $T_{2}, T_{1}$ and $T_{5}$, whereas the lowest available phosphorus (16.54\%) was obtained from $T_{0}$ treatment. The highest exchangeable potassium $(0.169$ me $\%$ ) was observed from $T_{3}$ treatment which was statistically similar with other treatment except $T_{0}$ and $T_{6}$, while the 


\begin{tabular}{lccccc}
\hline \multicolumn{3}{c}{ Table 3: Effect of plant growth regulator-flora on yield contributing characters and yield of transplanted aman rice } \\
\hline Treatments & $\begin{array}{c}\text { Length of panicle } \\
(\mathrm{cm})\end{array}$ & $\begin{array}{c}\text { Weight of } 1000 \\
\text { grains (g) }\end{array}$ & $\begin{array}{c}\text { Grain yield } \\
(\mathrm{t} \mathrm{ha})\end{array}$ & $\begin{array}{c}\text { Biological yield } \\
(\mathrm{t} \mathrm{ha})\end{array}$ & $\begin{array}{c}\text { Harvest index } \\
(\%)\end{array}$ \\
\hline $\mathrm{T}_{0}$ & $18.79^{\mathrm{d}}$ & $18.03^{\mathrm{b}}$ & $2.78^{\mathrm{e}}$ & $7.10^{\mathrm{d}}$ & $39.18^{\mathrm{c}}$ \\
$\mathrm{T}_{1}$ & $24.37^{\mathrm{ab}}$ & $20.44^{\mathrm{a}}$ & $4.24^{\mathrm{bc}}$ & $9.30^{\mathrm{a}}$ & $45.46^{\mathrm{ab}}$ \\
$\mathrm{T}_{2}$ & $25.05^{\mathrm{ab}}$ & $20.65^{\mathrm{a}}$ & $4.41^{\mathrm{b}}$ & $9.56^{\mathrm{a}}$ & $46.15^{\mathrm{a}}$ \\
$\mathrm{T}_{3}$ & $25.78^{\mathrm{a}}$ & $20.92^{\mathrm{a}}$ & $5.13^{\mathrm{a}}$ & $9.88^{\mathrm{a}}$ & $46.31^{\mathrm{a}}$ \\
$\mathrm{T}_{4}$ & $22.61^{\mathrm{bc}}$ & $19.68^{\mathrm{ab}}$ & $3.77^{\mathrm{cd}}$ & $8.29^{\mathrm{bc}}$ & $45.37^{\mathrm{ab}}$ \\
$\mathrm{T}_{5}$ & $23.95^{\mathrm{ab}}$ & $20.16^{\mathrm{a}}$ & $4.05^{\mathrm{bc}}$ & $8.88^{\mathrm{ab}}$ & $45.68^{\mathrm{ab}}$ \\
$\mathrm{T}_{6}$ & $20.16^{\text {cd }}$ & $19.21^{\mathrm{ab}}$ & $3.33^{\mathrm{d}}$ & $7.71^{\mathrm{cd}}$ & $43.11^{\mathrm{ab}}$ \\
$\mathrm{T}_{7}$ & $21.16^{\text {cd }}$ & $19.38^{\mathrm{ab}}$ & $3.41^{\mathrm{d}}$ & $7.97^{\mathrm{bcd}}$ & $42.78^{\mathrm{b}}$ \\
LSD ( $p=0.05)$ & 2.605 & 1.679 & 0.508 & 0.933 & 2.950 \\
Significance level & 0.01 & 0.05 & 0.01 & 0.01 & 0.01
\end{tabular}

In a column means having similar letter(s) are statistically identical and those having dissimilar letter(s) differ significantly as per 0.05 level of probability

Table 4: Effect of plant growth regulator-flora on nutrient content of post-harvest soil of transplanted aman rice

\begin{tabular}{lccccc}
\hline Treatments & $\mathrm{pH}$ & Organic matter (\%) & Total N (\%) & Available P (ppm) & Exchangeable K (me \%) \\
\hline $\mathrm{T}_{0}$ & 5.73 & 1.33 & $0.369^{\mathrm{c}}$ & $16.54^{\mathrm{e}}$ & $0.084^{\mathrm{c}}$ \\
$\mathrm{T}_{1}$ & 6.05 & 1.44 & $0.624^{\mathrm{a}}$ & $30.11^{\mathrm{ab}}$ & $0.160^{\mathrm{ab}}$ \\
$\mathrm{T}_{2}$ & 6.13 & 1.45 & $0.629^{\mathrm{a}}$ & $31.92^{\mathrm{a}}$ & $0.165^{\mathrm{a}}$ \\
$\mathrm{T}_{3}$ & 6.15 & 1.44 & $0.632^{\mathrm{a}}$ & $32.59^{\mathrm{a}}$ & $0.169^{\mathrm{a}}$ \\
$\mathrm{T}_{4}$ & 5.89 & 1.41 & $0.596^{\mathrm{ab}}$ & $28.32^{\mathrm{bc}}$ & $0.151^{\mathrm{ab}}$ \\
$\mathrm{T}_{5}$ & 5.94 & 1.41 & $0.613^{\mathrm{ab}}$ & $29.19^{\mathrm{ab}}$ & $0.160^{\mathrm{ab}}$ \\
$\mathrm{T}_{6}$ & 5.85 & 1.40 & $0.556^{\mathrm{b}}$ & $22.75^{\mathrm{d}}$ & $0.141^{\mathrm{b}}$ \\
$\mathrm{T}_{7}$ & 5.89 & 1.43 & $0.581^{\mathrm{ab}}$ & $25.55^{\mathrm{cd}}$ & $0.151^{\mathrm{ab}}$ \\
LSD ( $p=0.05)$ & -- & -- & 0.055 & 3.331 & 0.018 \\
Significance level & $\mathrm{NS}$ & $\mathrm{NS}$ & 0.01 & 0.01 & 0.01 \\
\hline
\end{tabular}

In a column means having similar letter(s) are statistically identical and those having dissimilar letter(s) differ significantly as per 0.05 level of probability

lowest exchangeable potassium (0.084 me \%) was recorded from $\mathrm{T}_{0}$ treatment.

\section{Conclusion}

Applications of RFD+2 times spray of Flora was the superior among the other treatments in consideration of yield contributing characters and yield of BRRI Dhan BR 11 (Mukta) in transplanted aman season under the agro-climatic condition of Sher-e-Bangla Agricultural University, Sher-e-Bangla Nagar, Dhaka.

\section{References}

Abel, S., Theologis, A., 2010. Odyssey of Auxin. In: Estelle, M., Weijers, D., Ljung, K., Leysers, O. (Eds), Perspectives in biology. Cold Spring Harbour Laboratory Press, USA.

Anonymous, 2014. BBS. Statistical Yearbook of Bangladesh.
Bangladesh Bureau of Statistics. Statistics Division, Ministry of Planning, Govt. of Peoples Republic of Bangladesh. Dhaka. Bangladesh, 64.

Anonymous, 2015. USDA (United States Department of Agriculture). 2015. World agricultural production, foreign agricultural service, circular series wap, 9.

Aziz, M.A., Miah, M.A.M., 1991. Effect of "Flora" on the growth and yield of wetland rice. Journal of Agriculture and Rural Development 7(1\&2), 9-13.

Banful, B.K., Attivor, D., 2017. Growth and yield response of two hybrid rice cultivars to ATONIK plant growth regulator in a Tropical environment. Environment, Earth and Ecology 1(1), 33-45.

Bhuiyan, M.S.H., Zahan, A., Khatun, H., Iqbal, M., Alam, F., Manir, M.R., 2014. Yield performance of newly developed test crossed hybrid rice variety. International Journal of Agronomy and Agricultural Research 5(4), 
48-54.

Chaudhary, S.K., Thakur, S.K., Pandey, A.K., 2007. Response of wetland rice to nitrogen and zinc. Oryza 44(1), 31-34.

Davidson, D.J., Andrews, J., Pauly, D., 2014. The effort factor: Evaluating the increasing marginal impact of resource extraction over time. Global Environmental Change 25, 63-68.

Ekamber, K., Kumar, M.P., 2007. Hormonal regulation of tiller dynamics in differentially tillering rice cultivars. Plant Growth Regulation 53, 215-223.

Emongor, V., 2007. Gibberellic acid influence on vegetative growth, nodulation and yield of cowpea. Journal of Agronomy 6, 509-517.

Fahad, S., Hussain, S., Saud, S., Khan, F., Hassan, S., Amanullah, A., 2015. Exogenously applied plant growth regulators affect heat stressed rice pollens. Journal of Agronomy and Cop Science 202, 139-150.

Haq, M.T., Sattar, M.A., Hossain, M.M., Hasan, M.M., 2002. Effects of fertilizers and pesticides on growth and yield of rice. Online Journal of Biological Sciences 2(2), 84-88.

Ma, L., Feng, S., Reidsma, P., Qu, F., Heerink, N., 2014. Identifying entry points to improve fertilizer use efficiency in Taihu Basin, China. Land Use Policy 37, 52-59.

Mohammed, A.R., Tarpley, L., 2011. High night temperature and plant growth regulator effects on spikelet sterility, grain characteristics and yield of rice (Oryza sativa L.) plants. Canadian Journal of Plant Science 91, 283-291.

Mohapatra, S., Tripathy, S.K., Nayak, B.R., 2018. Amelioration of herbicide stress with plant growth regulators and nutrients in transplanted rice. Indian Journal of Weed Science 50(2), 108-111.

Ndaeyo, N.U., Iboko, K.U., Harry, G.I., Edem, S.O., 2008. Growth and yield performances of some upland rice cultivars as influenced by varied rates of NPK fertilizer. Journal of Tropical Agriculture, Food, Environment and Extension 7(3), 249-255.

Pan, S., Rasul, F., Li, W., Tian, H., Zhaowen, M., Duan, M., Tang, X., 2013. Roles of plant growth regulators on yield, grain qualities and antioxidant enzyme activities in super hybrid rice. Rice $69,1-10$.
Prakash, N.B., 2010. Different sources of silicon for rice farming in Karnataka. Paper presented in Indo-US workshop on silicon in agriculture, held at University of Agril. Sci., Bangalore, India, 25-27 $7^{\text {th }}$ February 2010, 14.

Rahman, M.S., Sarker, B.C., Akhter, M., Bashar, M.A., Islam, M.R., 2017. Influence of residual lime and plant growth regulator (naa) on the morphological and physiochemical traits of aromatic rice cv. kataribhog. SAARC Journal of Agriculture, 15(1), 189-197.

Rai, M., 2006. Rice culture in agriculture: An Indian perspective. Proceedings of International Rice Congress, 7-8.

Sakamoto, T., Miura, K., Tatsumi, T., Ueguchitanaka, M., Ishiyama, K., 2004. An overview of gibberellins metabolism enzyme and their related mutants in rice. Plant Physiology 134, 1642-1653.

Shah, S.H., Ahmad, I., Samiullah., 2006. Effect of gibberellic acid spray on growth, nutrient uptake and yield attributes at various growth stages of black cumin (Nigella sativa L.). Asian Journal of Plant Sciences 5, 881-884.

Sharma, M.P., Bal, P., Gupta, J.P., 2003. Long term effects of chemical; fertilizers on rice-wheat productivity. Annals of Agricultural Research 24(1), 91-94.

Singh, H.P., Sharma, K.L., Ramesh, V., Mandal, U.K., 2001. Nutrient mining in different agro climatic zones of Andhra Pradesh. Fertilizer News 46(8), 29-42

Vetayasuporn, S., 2012. Effects of organic and chemical fertilizer on the Growth and Yield of Rice (Chai Nat 1). Research Journal of Biological Sciences 7, 265-269.

Wang, M., Ma, L., Strokal, M., Chu, Y., Kroeze, C., 2017. Exploring nutrient management options to increase nitrogen and phosphorus use efficiencies in food production of China. Agricultural Systems 163(C), 58-72.

Woodward, A.W., Bartel, B., 2005. Auxin: regulation, action and interaction. Annals of Botany 95, 707-735.

Yuan, L., 2014. Development of hybrid rice to ensure food security. Rice Science 21, 1-2.

Zhang, J., Zhang, S., Chen, L., Wei, C., 2017. Alleviation of seeding chlorosis by plant growth regulators in dripirrigated rice. Acta Agriculturae Scandinavica, Section B-Soil and Plant Science 67(2), 184-190. 